\title{
Stakeholders of public-private partnerships in Poland: an analysis of an evolving phenomenon
}

\author{
Tomasz Kusio
}

\author{
Kolegium Ekonomii, Finansów i Prawa, Uniwersytet Ekonomiczny w Krakowie, \\ Krakow, Poland
}

\begin{abstract}
Purpose - According to the growing role of stakeholders in the implementation of public-private partnership (PPP) initiatives, the purpose of this study is to diagnose the maturity of PPPs in Poland, taking into account the range of stakeholders' participation in public-private initiatives.

Design/methodology/approach - The introductory study on the stakeholders of PPPs has been based on the report analysis of Polish initiatives and the case studies' comparative analysis. The cases represent touristic projects realized within PPPs.

Findings - The results of the study indicate that the PPPs' personal context, though recognized internationally, is to a very low extent present in the Polish case. As the PPP market is still in the process of development, the stakeholders' issue should be taken into consideration in the processes of the PPP development in Poland.

Practical implications - As regional development is continuously a key issue, especially in rural areas context, the PPP initiatives are of great importance, and therefore the discussion of pros and cons in this context may contribute to the legislation at the regional level.

Originality/value - The study sheds some light and gives some interesting perspectives on the issue of the personal context of PPPs and social capital. Also, the text describes the path of developing PPPs in Poland and especially the touristic projects. The research part presents the original case study comparative analysis based on table-oriented form and as such enables the new way of contextual analysis.
\end{abstract}

Keywords Public-private partnerships, Entrepreneurship, Stakeholders, Social innovations

Paper type Research paper

\section{Introduction}

The description of the state of maturity of undertaking and implementation of public-private partnerships (PPPs) is well described in the international literature and, from Polish perspective compared to developed economies, this description is still not enough studied, which may be the reason for Polish PPP market development in continuous but initial progress. The main attention in this paper has been paid to the stakeholders of PPPs other than business and public administration. In addition to the very different approach to identifying stakeholders, attention was also paid to the effects of the implementation of activities other than those planned purposefully (economic profit and the implementation of regional strategies). What is particularly important today is the social reference there is why

(C) Tomasz Kusio. Published by Emerald Publishing Limited. This article is published under the Creative Commons Attribution (CC BY 4.0) licence. Anyone may reproduce, distribute, translate and create derivative works of this article (for both commercial and non-commercial purposes), subject to full attribution to the original publication and authors. The full terms of this licence may be seen at http://creativecommons.org/licences/by/4.0/legalcode

The publication was financed from the subsidy granted to Cracow University of Economics.

Analysis of an evolving phenomenon

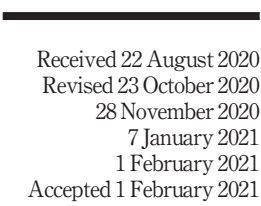

Accepted 1 February 2021 
IJOA

29,6

1484

social leaders and social organizations seem to have an increasing influence on regional initiatives, including PPPs, to which they are usually not parties.

The PPP option in terms of development is an interesting but sometimes the only possible way for the regional authorities to make necessary changes for society. This seems to be the general PPP advantage. The general rule for every economy is that the primary task of public authority is to serve and act for the public benefit, not to generate pure financial profits (Szumowski, 2019). Additionally, from the public administration perspective, reducing budget pressure, achieving social targets or productive efficiency are listed as some of the PPP projects' advantages. This refers to the PPPs at every stage, however, when stakeholders issue is taken into account, there may be a different approach. The PPP idea is to gain dual benefit both business operator and public partner, however, some additional advantages appeared. According to some researchers, in the process of creating and implementing PPPs, public partners become co-creators of the market, as well as asymmetric power relations (Laplane and Mazzucato, 2020) and this may be one of the stakeholders' issues as those of growing importance. Several topics of the PPP model such as risk management, critical success factors, value for money, economic feasibility, government role and concessionaire selection have been discussed (Ke et al., 2009; Hellowell and Pollock, 2010) and reducing budget pressure, achieving social targets or productive efficiency are listed as some of the PPP projects advantages (Zhang and Chen, 2013; Kwak et al., 2009). Those issues are still valid though their importance is raising through the perspective of stakeholders benefits. The stakeholders' issue while PPP characteristics are noticeable in international literature, but not so much in Polish papers.

As far as the PPP situation in Poland is concerned, the level of market saturation with PPP projects still remains low, which allows defining the market as underdeveloped. From an institutional point of view, in the context of Poland, PPP processes have strong legal foundations though. Public administration entities, which are interested in implementing partnerships in cooperation with business, are not legally limited to take these initiatives, apart from the issue of financial barriers. Barriers of legal and legislative nature are not strong enough so as to prevent authorities from deciding to undertake PPP projects which allows to positively assess these market perspectives. However, the less present aspect in the scientific analysis of partnerships, is a relational context, a thread related to stakeholders. While in the international dimension, i.e. European or global, the threads related to the discussion of partnership actors are undertaken, in the national - Polish context they are limited to the parties of the partnerships. This situation allows questioning if the stakeholders' presence, those other than PPP partners, may signify the PPP market maturity. The presented situational context is primarily the result of the generally low level of development of national PPPs as such. In developed countries, the evolution of PPP is entering the stage of expanding the partnership stakeholder base, while in Poland, the process of market saturation with PPP initiatives is still ongoing and is not yet completed. As the stakeholders other than PPP partners are a noticeable element of the initiatives and as the issue of the interest starts to be expanded while PPP initiatives not to be just private and public, the social dimension may be observed as this of a large significance.

Another issue of public-private initiatives, the specificity of which refers, inter alia, to increasing resource efficiency and better risk management, may also be related to corporate social responsibility (CSR) - the participation in these processes and the decisions of partners to become engaged in PPPs as additionally driven by the CSR benefits. This perspective is also reflected in stakeholders' issues. From one part of PPPs - entrepreneurs the participation in the implementation of socially oriented initiatives has an image dimension (social context). In the context of investment initiatives implemented by the 
private sector entities, the so-called socially responsible investments (SRI) are also indicated. For the entrepreneur, therefore, joining them is worthy due to the image benefit but also economic benefit as the long run is concerned. Therefore, the initiatives arising from social objectives have a wide range of benefits and this may be studied both from public and private perspectives.

Still another issue refers to the instrumental aspect of studies on PPPs which mainly concerns the models of their creation and functioning, while the phase preceding the partnership's establishment and concerning the personal issue, i.e. the initiators and executors

Analysis of an evolving phenomenon of initiatives within the framework of these partnerships, is less discussed, thus confirming the cognitive gap in terms of PPP relational dimension. The issues of establishing partnerships are mainly of an amendment to legal acts, regulating the accession and implementation of initiatives, mainly of an investment nature. Observation of the development of these regulations in the national context indicates the objectification of the issues of partnership formation. The personal thread of creating PPPs can be analyzed, among others, in the context of the expected benefits for leaders in creating these initiatives. The benefits that can be diagnosed on the part of the initiators of partnerships are both financial in nature and may primarily concern entrepreneurs, but these benefits also have a social and public dimension and should be addressed first and foremost to the public part of the partnership.

Although references to the benefits of PPPs are discussed, there is little discussion on the measurement of their social utility. The assessment of the level of usefulness before starting to make project decisions, not to mention the participation of potential final beneficiaries or their institutional representatives in the process, is also of less importance. The benefits of implementing partnerships are identified and the presence of social stakeholders is becoming increasingly noticeable, which in the case of Poland is only just beginning as observed. The importance of stakeholders is also identified in the phase of partnership implementation, where public utility is verified by the users themselves. Similar types of social behavior in relation to PPP initiatives in Poland do not yet exist or are not yet visible to the same extent as in developed countries. The mere perception of the possibility to determine the level of social stakeholder participation in the partnership conceptual or implementation phase may imply an assessment of the PPP market development. This is particularly important in countries where the PPP market is still underdeveloped. However, the direction of research that would fill the gap is to use stakeholders in the context of the impact of PPP projects on the level of social utility in the conceptual or implementation phase of these initiatives. This paper reflects an introduction to such considerations.

Benefits, in the context of stakeholders represented by persons, groups or institutions, who have direct participation in the phase preceding the establishment of partnerships, as well as in the phase of implementation of public-private initiatives, are of various character and the parties of the partnerships are again stakeholders with various motives in pursuit of the assumed objectives.

In PPP projects, the presence of persons or institutions, other than the parties to the partnership whose impact on the projects is noticeable, is increasingly evident in developed countries. This concerns the conceptual and implementation phase of projects. The degree of participation of stakeholders other than those directly involved in projects may determine the level of development of the PPP market, which can be confirmed in the analysis of PPP initiatives in Poland. The growing role of PPP stakeholders is connected, among others, with the identified benefits being the effects of PPP initiatives, however, not limited only to financial profits, which constitute a motivational stimulus for business or public benefits, which are designated by local government units that initiate projects. The cognitive gap that the attempt to fill in is part of the purpose of this work concerns Polish PPPs and in 
IJOA

29,6

1486

particular the stakeholders of these partnerships. In addition to trying to determine the state of the description of PPP phenomena in the literature, the main burden in this work will be to try to describe PPP stakeholders taking into account exemplary Polish PPP initiatives.

The main aim of the study is the attempt to diagnose the maturity of PPPs in Poland, taking into account the range of stakeholders' participation in public-private initiatives to gain the knowledge on relational dimension of PPP stakeholders. The following research questions have been formulated:

$R Q 1$. Are the analyzed partnership projects mainly infrastructural in nature?

$R Q 2$. What is the interest of stakeholders in joining PPP initiatives?

RQ3. Which partners take part in the implementation phase of PPP projects?

$R Q 4$. To what extent does the social factor matter in analyzed partnership projects and what is its contribution to the perception of project success?

RQ5. Do the information about the implemented projects contain end-users and to what extent do they have an impact on the conceptual or implementation phase in the presented cases?

The answers to the above research questions will allow gaining the information on the evaluation of the partnership maturity level from the perspective of stakeholders participation, the interest of business participation and personal engagement. Furthermore, by analyzing case studies it will be possible to obtain answers to the diagnosis of the significance of the human factor in the implemented projects in Poland. The literature analysis as well as the comparative analysis of five cases of PPPs, which took place in Poland, were used to obtain the study objectives.

\section{Literature review}

PPPs are defined in terms of the cooperation of a public partner and a private one created to attract private investment in the economy and, based on pooling resources, sharing risks (Anopchenko et al., 2019). PPP, in the categories of institutional model of interaction between government and business, is defined (Yatsechko, 2020) as a partnership between the government and the private sector for the provision of public and social goods or services due to its advantages in high efficiency of investment, resource allocation optimization, flexible market mechanisms, etc. (Song et al., 2019). This specific cooperation is recognized as one of the most common tools to formalize public and private sector relations and is used for any form of association or cooperation between those sectors for the purpose of delivering goods or services (Iacomino, 2019). Key criteria for classifying various types of partnerships as public-private categories are institutionalization, the presence of the government as one of the partners, the existence of joint goals, clearly identified state interest and joint investment of resources (Delmon, 2014).

PPPs are widely defined and characterized (Bovaird, 2004; Hall, 2008) and despite various approaches of interpretations, the need for the partners initiating and implementing partnerships to achieve economic and social goals can be considered as the common features. The thread of the parties to the partnership, therefore, refers mainly to the fulfillment of legal conditions for the establishment of the partnership. In turn, in a relational context, based on social capital one of the characteristics of partnership that can be used to describe stakeholder relations is solidarity (Sedjari, 2004). Another feature mentioned is mutuality, yet another the need to maintain the partner organization's image and organizational culture and this underlines the stakeholders' approach. Additionally while 
the search for relational threads, in definitions of PPPs, the wide and narrow perspective can be identified, where the first includes any type of partnership, regardless of the rules applied to its implementation and the second type is closely related to compliance with the law: guidelines related to them, related in the partnership being created according to laws and regulations (Cieślak and Korbus, 2014).

Taking into account the national (Polish) context, then according to the provisions of the Act of 19 December 2008 on PPP (Act) (Ustawa $z$ dnia 19 grudnia, 2008; r. o partnerstwie publiczno-prywatnym, 2009), there is a predetermined public representation for creating partnerships. This is the definition of a public entity, outlining the group of entities obliged to apply the Act. These are:

- public authorities;

- local government units and their unions;

- budgetary units;

- local government budget establishments;

- implementing organizations;

- institutions of the budgetary economy;

- state earmarked funds;

- Social Insurance Institution and funds managed by it and Agricultural Social Insurance Fund (KRUS) and funds managed by the President of KRUS;

- National Health Fund (NFZ);

- independent public health-care facilities;

- public universities;

- The State Academy of Sciences and the organizational units created by it;

- state self-government cultural institutions and state movies institutions; and

- other state or local government legal persons established under separate acts to perform public tasks, excluding companies, research institutes, banks and commercial companies.

The above-mentioned institutions and units can be simply referred to as legally listed stakeholders of PPPs in the Polish context. In addition to the above mentioned and covered by the Act range of entities obliged to apply PPP regulations, the State Treasury companies are also those allowed to apply PPPs. Although until now PPP has been associated to a large extent mainly with the two sectors, the role of non-governmental organizations and the society itself is increasing, which may be explained, inter alia, by the rising importance of self-governments on both local and regional level. Thus, PPP can also currently be classified as one of the categories of initiatives, alongside:

- Social and Business Partnerships (SBP);

- Public-Public Partnerships (PPP); and

- Transversal Partnerships (TP).

The implementation of partnership initiatives can, therefore, be considered in a broader perspective in the era of social economy development when social factor gains importance.

The regional and local context in terms of inter-sectoral partnership is another issue. It points to the changing trend of urban and rural development in research from policy-led to multi-sector participation for more livable urban ecosystems. Multi-sector regional and local
Analysis of an evolving phenomenon 
IJOA 29,6 partnerships involve the participation of multiple actors (institutions, agencies, individuals) in development initiatives, providing resources to achieve the expected objectives and their identification is from the third sector stakeholders perspective the most effective. Partners' selection for specific development initiatives is performed by identifying the resources they are able to provide due to their values and interests (Xue et al., 2020) and the local NGOs are key actors as those highly acknowledged in local problems. It is about life-enhancing conditions within communities as is defined in literature as social sustainability (McKenzie, 2004). The recognized importance of not just social but also regional and local dimensions in the development of innovation is reflected in smart regional specializations, where the success of the projects consists precisely of the cooperation of various regional stakeholders. Wide segmentation of stakeholders during the project implementation has an impact on its course, taking into account the issues of better attitude toward the expected project results. The regional context in PPP initiatives can also be analyzed in terms of their scope. Another project perspective refers to projects with a smaller territorial scope - local projects and another to projects with a wider scope - regional projects.

Both regional and local PPP, TP, SBP actors are obliged to follow the legal regulations, however, the barrier appears of over-bureaucratization in terms of the issue of partnership formation and its functioning. In this context, the regulatory system to encourage joint ventures seems to be necessary, as well as undertaking and implementing effective projects. The issue of effectiveness in relation to the PPP implementation is to a large extent related to stakeholders and the high level of their satisfaction is an increasingly important measure of project success. The more advisability of creating PPPs is recommended, the higher level of effectiveness of these projects, which is increasingly measured in terms of the level of satisfaction of final recipients of the project.

The stakeholders' issue refers to the increased effectiveness of PPP which results, among others, from a shortened communication chain. In the case of consulting projects between users and service providers in PPP projects, users have the opportunity to directly submit comments to the provider, which is a private entity. In the case of the realization of exclusively public projects, the consultation process is prolonged (Nordtveit, 2005). When it comes to flexibility in adapting to the needs of end-users, the issues of bureaucratization of regulations and institutionalization in general, in the context of PPPs, may constitute a serious barrier to the implementation of initiatives. They are very important because regulations concerning public funds are subject to very strict social control. These include the selection of business partners for publicly initiated projects and the benefits that these partners derive from using the results of PPP projects. While the considerations on stakeholder interrelationships between the partners are mentioned in the definitions given, it is also stated that, above all, the partnership is mainly based on the business context and the benefits that result from the sharing of responsibility and risk (Mouraviev and Kakabadse, 2016).

The institutional threads of creating PPPs seem to be dominant in the considerations. However, despite the purely regulatory issues concerning the principles of creating these partnerships, as well as the principles of contract formulation and other institutional threads, little attention is paid to the issue of partnership and personal relations between stakeholders though initiatives are carried out by people and the personal and social thread is crucial to the success of the projects. Regulatory issues address many of the elements among which the mutual referencing of partners also applies, but the dimension of creating and shaping the relationship is an important issue, especially at a time when a sustainable, balanced success is expected. However, the human factor is beginning to appear due to the growing importance of stakeholders. Therefore, the public, private, people and partnership (4P) model (Maraña et al., 2020), which complements the set of public-private project 
stakeholders, also appears among discussions dedicated to PPP stakeholders. Also, in addition to PPP stakeholders, who are parties implementing socio-economic projects, other parties should be considered as involved including public recipients, i.e. users (Wang and Gao, 2020). Their evaluation of the utility of the services provided through the project, i.e. the level of public satisfaction, depends on the level of evaluation of the public partner. This is one of the outcomes of the satisfaction of the public institution that is the project partner (Wang and Gao, 2020). End users, as has been indicated, can also take an active part in the implementation of a given project, e.g. during the infrastructure design phase, they can

Analysis of an evolving phenomenon

1489 make comments about social needs, about the existence of which or the specifics of which the public authorities may not know. The research results confirm that the stakeholderengagement-related strategies are key to manage the issues in PPP projects (Jayasuriya et al., 2020). The importance of social participation in stakeholder-engagement-related strategies is also very important as it increases the likelihood of PPP projects, success (Dansoh et al., 2020). They include, among others, the significant role of mutual interaction, the relationship with institutionalization, materialized by the agreements signed (Andersen, 2004). The formula from cooperation to a partnership or vice versa underlines the issue of relations, where the personal context gains importance in partnerships and not just PP but cross-sectoral partnerships as well.

The direction of relations, i.e. decreasing their formalization or increasing their formalization may be determined by whether the project objectives will be more financial or more social in nature. The determinant of undertaking public-private initiatives, represented by the call announcement, is also the reason for the possibility to implement a social and economic project for a local community. Clearly, the issue of differentiation in the distribution of benefits for the parties undertaking the project is of great importance, as these benefits are both financial and social. For the business partner, the financial determinants are much more important, while for the public partner the public dimension of the project should be the priority. It is about economic efficiency, to be measured not only financially but also in terms of social benefits. However, for a PPP project to come to an effect and the partners to start the initiative, it seems necessary to achieve the winning effect, i.e. the state of perception of benefits from joining the initiative by both project parties (Carbonara and Pellegrino, 2018), i.e. by project stakeholders.

\section{Stakeholders of public-private partnership}

By their very nature, stakeholders in PPPs are public entities, business sector actors, i.e. private entities. Among stakeholders classification methods the most common is the one according to threat and cooperation (very important, helpful, not helpful, marginal) according to the level of strength, influence and influence on the organization (definitely with all attributes, with two attributes, hidden with one attribute, neutral without any attribute). Finally, stakeholders can also be classified according to their position in relation to the project initiator, i.e. the public entity, into internal and external. When identifying stakeholders of PPPs, the following categorization can be distinguished (Kołodziej-Hajdo, 2018):

- entities representing the public sector;

- private sector entities, e.g. project contractor, financier, insurer, media, etc.; and

- direct beneficiaries of the project, e.g. users of the infrastructure created within the framework of the project, using services of the community living in the area of project impact, etc.

Still another identification of PPP stakeholders refers to the parties with a positive attitude to joint initiatives and on the other hand those with a negative one. Among the negative 
IJOA

29,6

\section{0}

\section{Figure 1.}

Stakeholders and types of relations between them sources that encourage local stakeholders to be reluctant to take public-private initiatives one can distinguish (Argiolas et al., 2000):

- competition between private companies;

- competition between political parties;

- economic diversification;

- civic participation;

- political culture;

- the political orientation of leaders; and

- characteristics of individual local leaders.

The above-presented qualifications refer to institutional stakeholders, while in terms of individual projects the following can be made (Elias et al., 2002):

- project manager;

- project team;

- financial institutions;

- customers/contractors;

- suppliers/contractors;

- employees;

- government institutions and agencies;

- media;

- groups of particular interest; and

- the local community.

The stakeholders of public-private projects can, therefore, be territorially identified. In the case of regional initiatives, the regional authorities will be most strongly engaged and subsequently in a narrow perspective i.e. communal, in a district or other areas that do not go territorially beyond the region, the local representation of public authorities are playing the key role. This underlines the significance of local NGOs as key actors on the local or even regional level. Figure 1 graphically presents the stakeholders and the types of relations between them, in the regional and local areas.

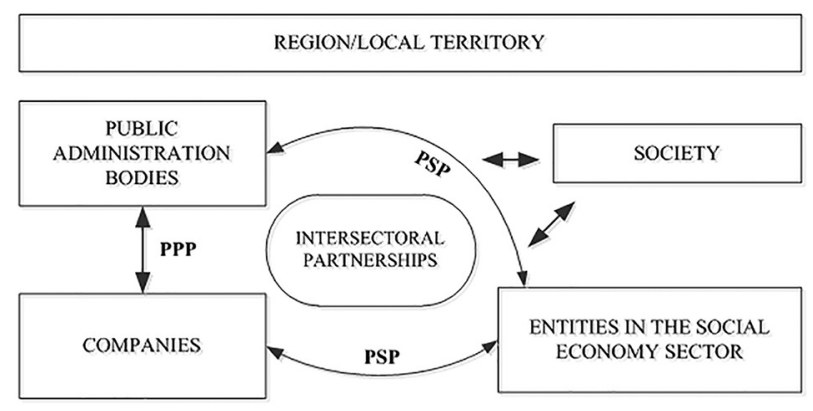

Source: Own elaboration 
Local development complements regional development. Local development is a measure taken at the will of local actors (local governments, business entities, social economy entities) (Brandenburg, 2011) on the basis of a reflection on the valorization of local resources and taking into account the territorial specificity (Pietrzyk, 2001). In turn, the basic factors of local development can be considered as (Parysek, 1992):

- the needs of the inhabitants;

- resources and values of the local natural environment;

- infrastructure investment;

- level of education, community culture;

- existing economic, scientific, technical and human resources potential;

- favorable legal provisions;

- active local community and a favorable attitude of local authorities to the initiatives undertaken;

- the labor resources;

- local and external markets;

- financial capital, especially investment capital;

- modern manufacturing technologies;

- $\quad$ area and benefits of the site; and

- international relations and bilateral cooperation.

Both local development and regional development are influenced by different stakeholder groups. The existing formula of cooperation between private and public entities is expanding. Social economy is becoming increasingly important in regional development. In addition to PPP, the example of the so-called intersectoral or transversal partnership (as indicated earlier in this text) is also worth mentioning, which is created by partners representing various sectors, including commercial, public and non-governmental. In its assumption, in creating a partnership, all those joining it bear a common risk and share the benefits resulting from the implementation of both collective and individual objectives (Jakiel, 2019).

Among the perceived irregularities in the functioning of intersectoral partnerships, there are, among others: opportunism, covert intentions of cooperation and manipulation, emerging conflicts or problems with responsibility. The above-mentioned problems in the functioning of partnerships can be characterized as personal, such that are largely based on the personal resources of cooperating organizations. The goals of business cooperation are usually identified with the co-creation of value for the owners, while for public entities, the goals concern creation of value for stakeholders (Kozarkiewicz and Bochenek, 2018). The rationale for undertaking inter-organizational cooperation, which is currently being addressed with a significant increase in importance, includes (Lank, 2007):

- preference for activities in the public interest or for the common good;

- to operate in the same local environment;

- the existence of a system of personal relationships;

- complementary organizational competencies;

- good interpersonal relations with potential partners;

- close location of the premises;
Analysis of an evolving phenomenon 
IJOA

29,6

1492

Figure 2.

Process of

cooperation between

a non-profit

organization and a

commercial entity
- the possibility of using the good relations with the environment such as relations with clients; and

- market credibility.

The implementation of initiatives in the formula of PPP seems to be particularly important in the context of social economy entities, which in the idea of their activity combine social integration with professional activation, entrepreneurship with counteracting exclusion, economic development with increasing social activity of the inhabitants (Lojko, 2018). Local partnerships, in the implementation of which social economy entities are involved, are established mainly to solve important social problems. Figure 2 presents the process of cooperation between a non-profit organization and a commercial entity.

Non-profit institutions, when they need to acquire a partner arises, specify the characteristics they expect from potential collaborators, which can be described as the partner's social capital, material and non-material resources held. This is the only way to identify entities with such resources. As a result of fruitful cooperation, a fruitful climate of cooperation and building partnership relations may be created. The element of social capital is also present among determinants of choosing the PPP formula by the public sector, as presented in Figure 3.

Stakeholder participation in local and regional activities is all the more significant the smaller the area or region (Festa et al., 2019) as indicated by the results of wine market research. At the same time, the stakeholders operating in the local or regional dimension, forming a network of stakeholders, are not always equally prone to undertake and participate in initiatives implemented in a given area (Conto et al., 2012).

The first step in building an atmosphere conducive to cooperation and participation, when it comes to the creation of PPPs, can be seen as supporting positive relations between organizations and members of the local community (Argiolas et al., 2000). Territorial development includes the location of locally competitive goods (Crouch et al., 2001), which

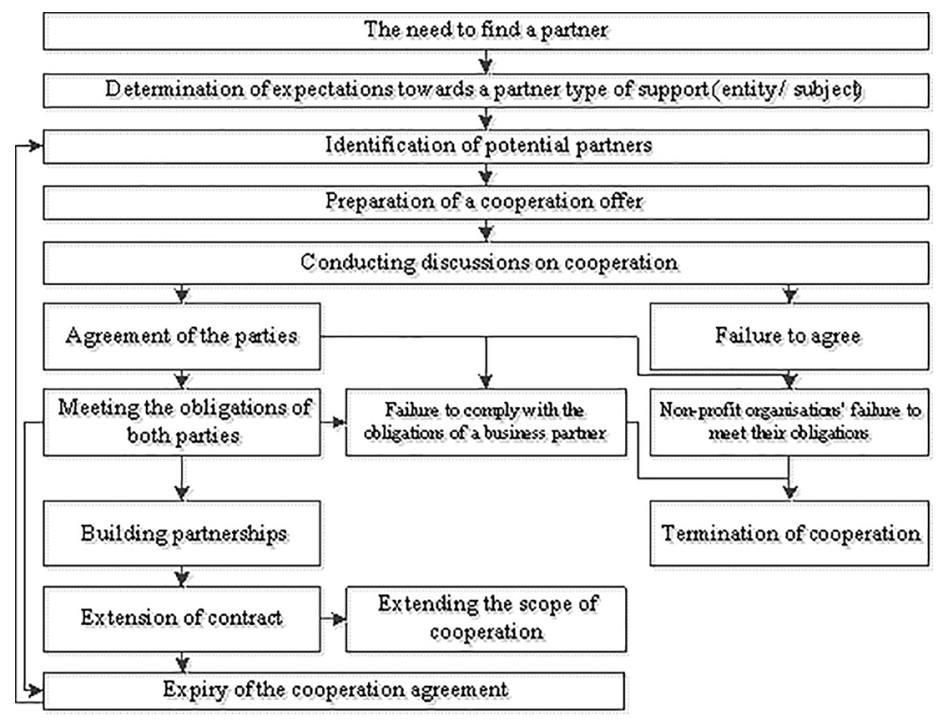

Source: Fudaliński (2013) 
FINANCIAL
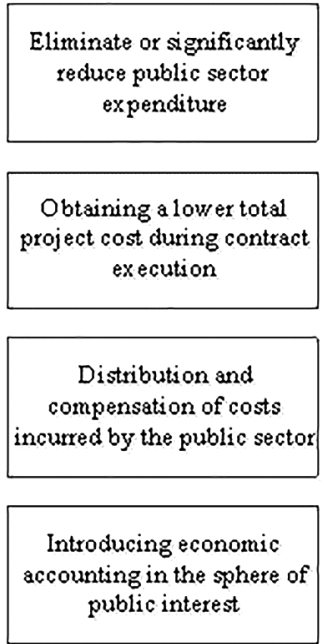
Possibility of bypassing a budgetary constraint (accounting motivel debt recognition)

Source: Kotas (2009)
ORGANISATIONAL AND TECHNICAL
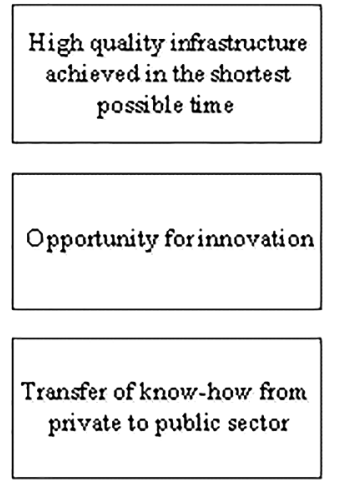

Risk optimisation opporturities
SOCIAL
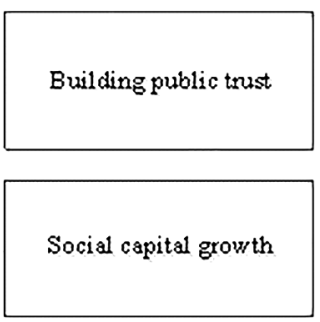

1493
Figure 3.

Determinants of public sector choice of PPP formula

are linked to the culture of the region, the local community concerned. Initiatives that are implemented in the formula of PPP, implemented by social representatives and residents, also at the stage of deciding on an initiative, are activities that strengthen the participatory character of the development of a given region. In this case, local communities constitute a favorable group of stakeholders and social economy actors are of significant importance.

Each of the stakeholder groups that take part in public-private or sectoral initiatives is accompanied by different premises for undertaking relations and joining PPP initiatives. The business has its own premises, which are based on achieving expected economic effects, while the public sector is mainly interested in the satisfaction of public stakeholders. For the social economy sector, the social good is accompanied by economic calculation as well.

Summarizing, in the global dimension, the importance of the stakeholder context (especially those stakeholders representing the third sector) of PPP projects is growing. There is not just the number of stakeholders in PPP projects that is growing but also the role of end-users of these initiatives. In the national context, the number of initiatives is increasing and the problems are mainly in the implementation phase of PPP projects. Not only is it far from the phase of saturation of the domestic market with the results resulting from completed partnership projects but also the lack of saturation with projects in the implementation phase. The level of maturity of PPP processes in Poland, which in the European or global context determines the increase in the importance of stakeholder involvement, is the subject of further considerations. 
IJOA
29,6

1494

\section{Public-private partnership in Poland}

The process of implementation of PPPs in Poland started at the end of 2009 when the relevant legislation was implemented. From 2009 to 2015, the number of PPP calls reached 425 , of which only 119 were successful in selecting a business partner. The average contract value was $€ 13 \mathrm{~m}$ and half of the contracts did not exceed $€ 1.7 \mathrm{~m}$. The characteristics of the PPP situation in Poland are mainly local, over $70 \%$ of PPP procedures were announced by municipalities and the PPP market can still be described as developing (Węgrzyn, 2018). Projects implementation in the formula of PPPs in Poland is more concentrated in richer regions (voivodeships). In six voivodeships 89 PPP projects are implemented and in the remaining 10 voivodeships: 33 projects. The richest voivodeships realizing the largest number of PPP projects also have the largest number of registered entrepreneurs per 10,000 inhabitants, the largest GDP per capita or the largest added value per capita (Godlewska, 2018). A similar result of the lack of mutual trust of partners or mainly the lack of trust of public partners in the activity of private partners may be a result of the underdeveloped PPP market in Poland. On the other hand, when it comes to the lack of response from the business sector to the offers of cooperation for realizing PPP, the provisions of agreements is a reason, where the private party would bear the greater part of economic risk connected with realizing an enterprise (Tereszko and Pec, 2018). Still, as can be learned from the literature analysis, the maturity of the PPP market in Poland is low. The market saturation has not yet been achieved through this varies between regions. Richer regions are characterized by a higher level of PPP market maturity. However, in the context of the level of development of PPP processes themselves, this maturity remains low. As the literature presents PPP model is still based solely on the public partner - business partner formula. A similar partnership structure is far from the multi-stakeholder (4P) model, with a wide range of stakeholders.

As a result of a survey conducted in Poland in 2017 on the motives for undertaking interorganizational cooperation by public institutions, the highest percentage of responses $(76 \%$ of indications) concerned increasing the chances of obtaining funding for an undertaking from external funds because of the experience and resources of the partner, the leader. Another important factor in undertaking cooperation (63\% of responses) was an increase in the likelihood of achieving project objectives and their results. In total, $42 \%$ of indications concerned the reduction of the costs of project implementation and 38\% indicated the lack of possibility of independent project implementation due to financial, human and technical resources (Kozarkiewicz and Bochenek, 2018). Other important reasons for undertaking cooperation concerned the possibility of gaining experience in the implementation of projects $(30 \%)$, supplementing the competence and staff with human resources of the partner/leader (51\%), as well as learning and acquiring knowledge to acquire new competencies $(28 \%)$. The results of the research show that public entities prefer to cooperate with entities they know, with which they have already cooperated or are somehow connected with them. On the other hand, in response to the reasons for not establishing cooperation with other entities, the first place was given to the lack of a proposal of such a form of cooperation by other entities $(32 \%)$, while the second place respondents only indicated the lack of an appropriate partner to implement a joint project.

Surveys conducted among urban and rural communes in Poland in the context of premises prompting entities to take initiatives in the PPP formula show that although there are noticeable weak correlations in the context of, among others, the size of projects or the duration of projects and financial, organizational, technical and social factors, the problem of precise identification of these determinants still remains. The higher the level of financing, i.e. the larger the project is financial, the higher importance of the remaining determinants, which for smaller projects decreases. There is also a difference in the perception of the 
prerequisites for realizing PPP projects in terms of the level of urbanization of communes (Kotas, 2009). The literature confirms that a project implemented in the PPP formula is initiated by a public entity - the desire to cooperate (Weqgrzyn, 2018). As far as the level of mutual trust between public and private partnership stakeholders in Poland is concerned, opinions are divided. Some authors believe that partners have limited trust (Godlewska, 2018).

The issue of trust is a well-established thread in terms of the characteristics of PPPs. Trust, which is an element of social capital, influences the building of relations, their strengthening and enhancement. Thus, trust as a determinant of increasing social capital also influences the number of partnership stakeholders and the strengthening of ties, which may also increase the level of interest in undertaking PPP initiatives and may be important for the development of partnerships in Poland. It is worthwhile to monitor, on the basis of the partnerships implemented so far, the relationship issue, participation and importance of stakeholders in national partnership projects.

\section{Research methodology}

To gain knowledge on the level of maturity of PPPs in Poland, case studies of five tourism initiatives from Poland have been analyzed $(1,2,3,4,5,6,7,8,9,10,11)$. The choice of PPP initiatives had been made with reference to the existing EU funding and the possibility of obtaining financial support (Korbus et al., 2016). Another issue has been to concentrate on the local dimension and the method of selection of the described initiatives has been subject to the criterion of realization in the past five years in Poland (though some had been started earlier). A natural criterion for the identification of development initiatives was the leading formula of project implementation through public-private cooperation. National initiatives are directed mainly at the implementation of activities of a promotional and touristic nature, which results mainly from the requirements of financial support based on EU funds. The following aspects of the cases have been analyzed to present the general assumptions of the initiatives:

- $\quad$ purpose of the initiative;

- nature of the project;

- number of tenders submitted;

- success factors;

- type of resources involved; and

- effects and perspectives.

\section{Research results and discussion}

The analysis of individual PPP projects in Poland identified on the basis of the national literature was first conducted by identifying information according to the criteria presented in the methodological part and then entered in the table. Due to the tabular form, it is possible to compare information from as many as five cases of PPP initiatives more clearly. Table 1 contains data on the five cases of PPPs.

An analysis of national and international literature on PPPs was used to obtain information relating to decision-makers in the field of PPPs. The main reference was made to national literature, taking into account the national, Polish context. The literature analysis shows that in the national context the level of implementation of development initiatives in the PPP formula is still low, which is mainly influenced by financial and bureaucratic
Analysis of an evolving phenomenon

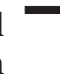


IJOA
29,6

1496

Table 1.

Comparison of Polish public-private partnership projects in the area of tourism

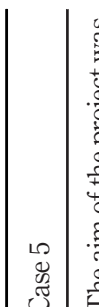
Mnting

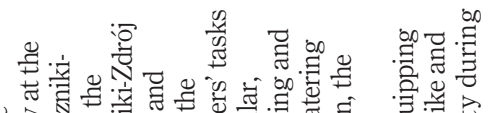

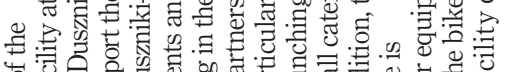

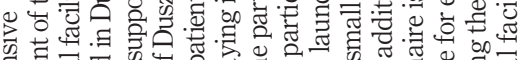

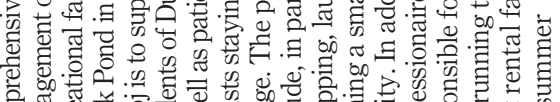

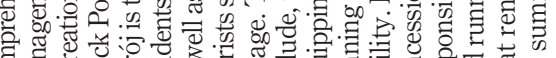

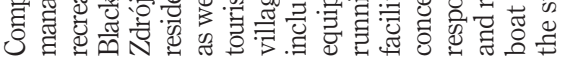

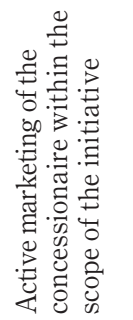

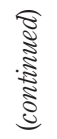

की

舟政

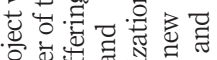

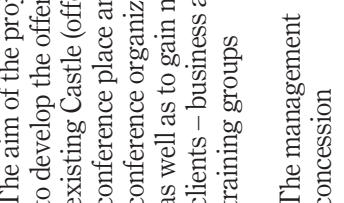

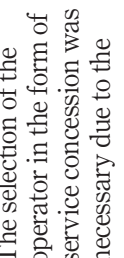

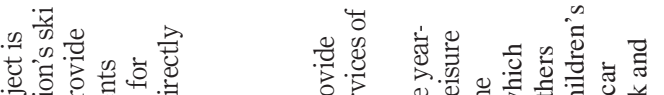

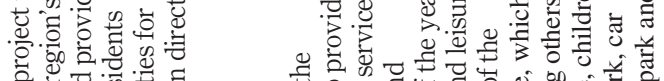

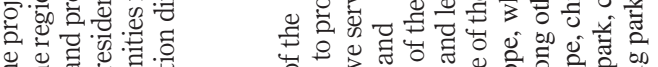

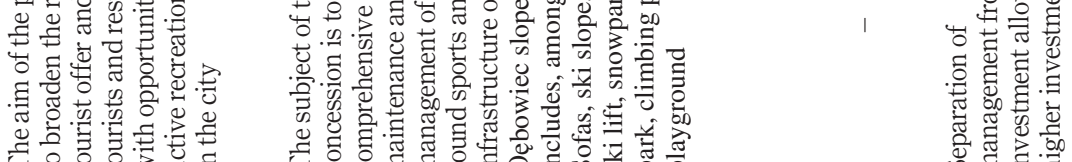

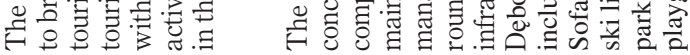

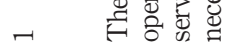

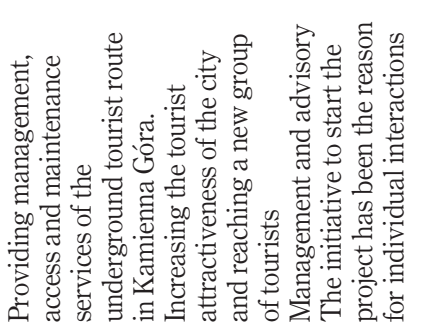

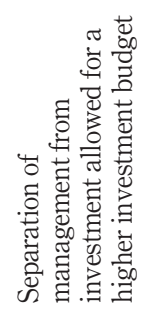

.

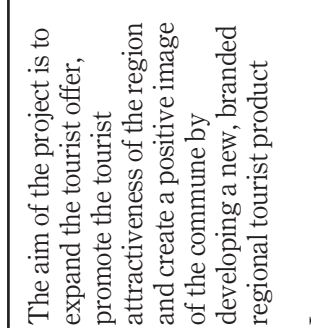

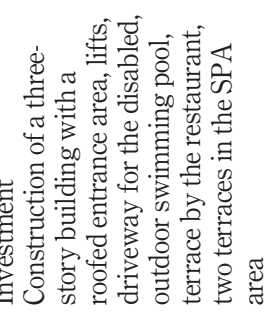

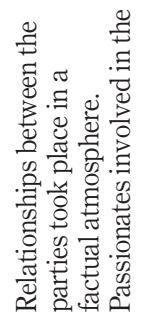

-

(2)

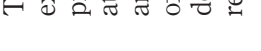

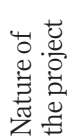

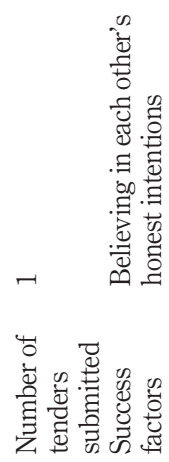




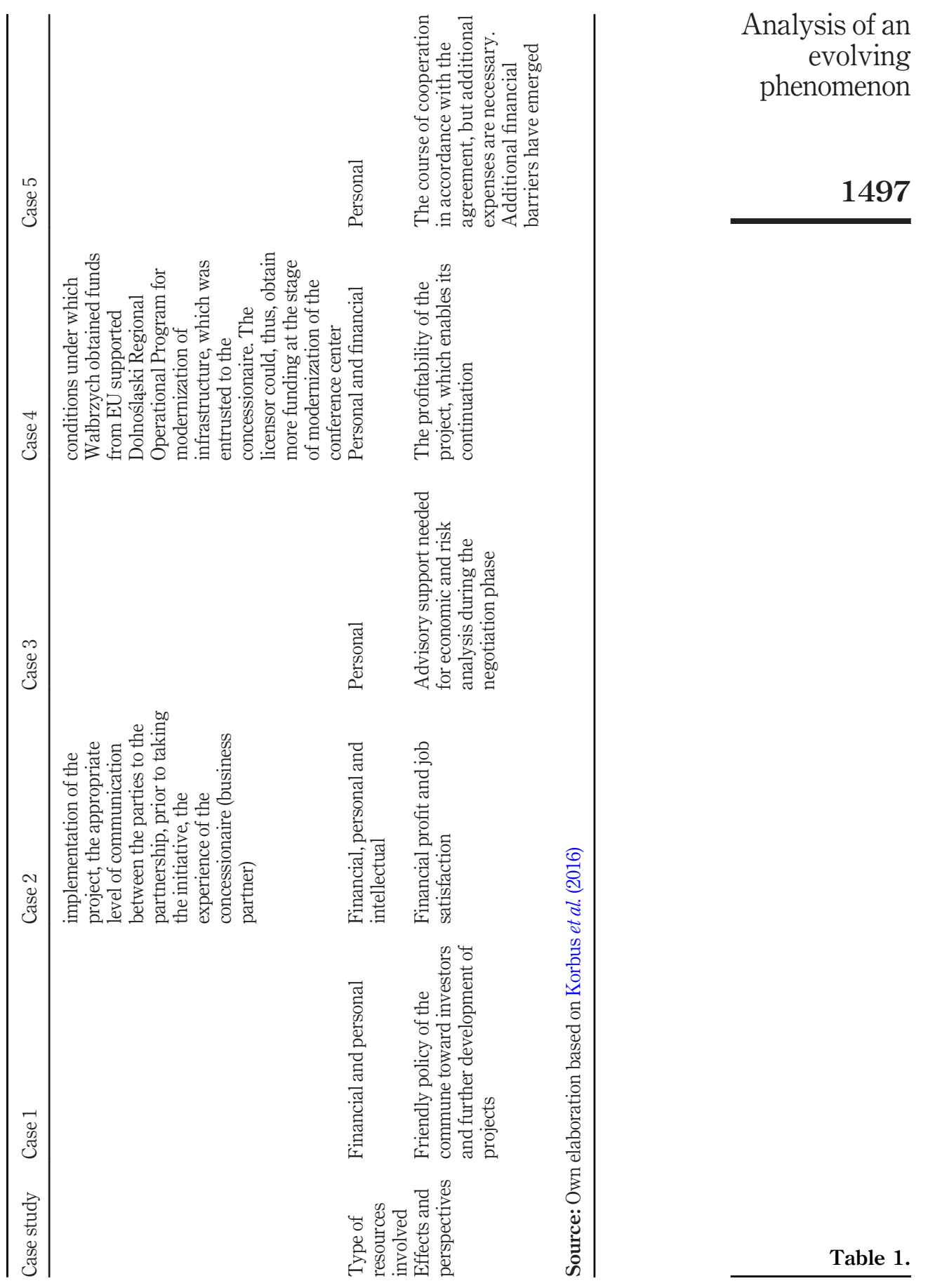


IJOA

29,6

1498

barriers. It is also difficult to expect that it will be possible to overcome both barriers in the short term. On the other hand, a personal issue may be important in this respect. Entrepreneurship and the will to create development initiatives can have a significant impact in reducing the risks of undertaking partnership initiatives.

As a conclusion, arising from the literature analysis carried out in relation to PPPs, it is possible to indicate that the cooperation initiatives are still relevant and effective. What is more, it seems that in the national Polish context the phenomenon of undertaking these initiatives is still not at the expected level, which means the number of initiatives is not sufficient. This results from a comparative analysis with other European countries. The legislation on partnerships may be described as still burdened with barriers. There are also concerns mainly on the part of public administration, the implementation of such initiatives. The business part also has to take into account the dangers of the occurrence of additional costs unpredicted at the planning stage. In this case, the decisive factors that may be considered to influence the increase in the level of initiatives are financial and personal factors, in the presented order.

The analysis of respective PPPs indicates mostly mutual goals of these undertakings, aimed at increasing the attractiveness of the region. This seems to naturally express the objectives of the financial priorities of the financing programs used by national public administration units. Moreover, raising the level of regional attractiveness is still a response to infrastructural deficiencies in Poland and indicates the need for supplementing material and infrastructural resources. A similar approach is confirmed if the resources involved are compared, where only for one project are personnel resources and in other cases financial resources. Public administration units and business partners in most cases carry out infrastructural projects. Thus, the first research question can be positively addressed, i.e. whether the partnership projects were mainly infrastructural. The answer confirms the initial stage of maturity in relation to the implemented national PPP initiatives. Most of the analyzed cases were related to infrastructure. Thus, there is no distinction in the realized projects and the main emphasis is put on infrastructure. In terms of comparing the results of the analysis of the implemented initiatives with the results of the literature analysis, the theme of PPP maturity level in Poland is confirmed.

With respect to the second research question concerning the interest of stakeholders in joining PPP initiatives, it should be stated, bearing in mind the number of bids submitted, that it is practically nonexistent. Therefore, in each of the analyzed cases, the number of submitted bids from a business partner was only one and in one case it was not possible to find information on this issue. This is confirmed by the still undeveloped domestic PPP market. However, it is difficult to determine at what stage this market is located. The analyzed projects of standard PPP initiatives, despite the fact that they are based on a solid institutional foundation, still seem to be, in a way, identical in terms of objectives and scope of stakeholders.

In the context of the nature of the project, as one of the variables that were adopted to describe individual initiatives, a distinction can be made between investment, management and advisory, nature. These are specific characteristics that relate to the purpose and subject matter of the initiative, as well as to the role that the partners play in the project. On the other hand, when analyzing the effects of initiatives and perspectives from the partners' point of view, it is noticeable that there is a thread of mutual relations between internal stakeholders, i.e. project partners. The thread of mutual relations can be referred, among others, to the opinion about satisfaction from work and the noticeable friendly policy of the commune toward investors. The information about the need for advisory support in the field of economic and risk analyzes also appeared. 
The effects identified during the analysis of respective PPP cases concern not only the financial sphere (profit and profitability) but also the assessment of mutual relations, which appears in the perception of project results. Among the evaluation of realization of partnership projects, there is also an indication of the need for support preceding the accession to the PPP initiative. It concerns advisory support in the scope of economic and risk analyzes. Stakeholders perceive the future in a positive way when it comes to assessing cooperation. What particularly draws attention is the appearance of a relational thread in the evaluation and development perspectives of PPP projects. This personal thread also appears in the success factors indicated in the descriptions of the respective initiatives, which are also presented in Table 1 . In the case of the assessment of factors that influenced the success of the initiatives, the relational element and trust are already clearly noticeable. This is due to the fact that the belief in the honest intentions of the other party and the relationship between the parties, which took place in a factual atmosphere, the appropriate level of communication between the parties in the partnership is indicated.

The above-identified characteristics of the implementation phase of PPP projects allow us to respond positively to the research question concerning the participation of the social factor in the perception of project success. This factor is noticeable and assessed as determining the success of the project. Unfortunately, with regard to the analyzed cases of partnerships, it was not possible to identify information concerning the participation of endusers, which can be interpreted as a lack of their participation. The lack of end-user participation in the conceptual phase of the project indicates, on a national level, the immaturity of PPP processes. There is also a lack of any information on the influence of endusers on the project implementation phase, which allows answering the last research question negatively.

Among the information concerning public-private projects, there is also insufficient information on the participation in partnerships of entities other than business and public administration, which also allows answering negatively the third of the research questions formulated at the beginning.

To deepen the knowledge on the level of maturity of PPPs in Poland, as well as to obtain updated information on projects implemented in Poland, case studies of five freely selected PPP initiatives in the field of regional promotion were taken into account. Economic development in the area of tourism and promotion of the region represents the activities of each public administration unit in the country, despite the fact that some communes or poviats are characterized by a greater or lesser interest in the implementation of supporting activities in this area.

The objectives of the initiatives show the level of similarity of the projects and at the same time allows for obtaining information on the directions of undertakings which are implemented in Poland in the formula of PPPs. The description of the nature of the project contains information on the orientation of the project provider's needs and the directions of demand for specific resources. The number of submitted bids indicates the level of interest of the bidders in a given initiative, but may also be a source of knowledge on the barriers to the implementation of initiatives under the PPP formula. The success factors that have been analyzed are intended to identify the factors and among them the personal factors that have been identified as key by the initiative contractors. Similarly, the effects and perspectives which were identified to show the contractors' opinions on the identified factors positively and negatively determining the undertaking and implementation of PPP initiatives now and in the future. On the other hand, the type of resources involved indicates mainly the need for resources in the context of PPP in Poland.
Analysis of an
evolving
phenomenon

1499 
IJOA
29,6

1500

\section{Conclusions, recommendations and implications}

As regional development is continuously a key issue, especially in rural areas context, the PPP initiatives are of great importance, and therefore the discussion of pros and cons in this context may contribute to the legislation at the regional level. The literature indicates the increasing commitment of the social side in both the conceptual and implementation phase of PPP projects. This is particularly relevant for the end-users of projects, who are at the same time voters, from the point of view of candidates from public administration. The level of satisfaction of end-users of PPP projects is becoming increasingly important, which at the same time emphasizes the growing status of the human factor.

The initiation of public-private projects comes generally from the public sector. Decisions on the implementation of specific projects result from current public and social needs and the local needs are best perceived by third sector organizations functioning in the local environment. Public entities when implementing initiatives are generally focusing on planned activities, which are written down in development strategies. The issue of territorial reference in the implementation of initiatives between partnerships affects the possibility of separating local and regional projects. Territorial development planning, therefore, provides a definition of how to divide development strategies into local and regional ones, as well as partnerships for implementing planned activities. Starting the initiatives is, as indicated in the Polish context, the domain of the public part, which often does not have sufficient resources to achieve the objectives described in development strategies.

Within the framework of research conducted so far in Poland on PPP (Blicharz, 2010), taking initiatives on the implementation of tasks is mainly related to the level of financing of tasks - the greater the financing, the lower the inclination to undertake these tasks, as well as to the level of difficulty in the implementation of tasks, the easier it is to determine the risks and the simplicity of the task to be performed, the greater the inclination to undertake partnership. For entrepreneurs, it is not the level of rates and discounts that has a greater impact on undertaking initiatives, but the stability and transparency of applied fiscal solutions (Makieła, 2008).

The main types of risks, especially those mentioned in PPP, are the risks of financing and maintaining the infrastructure only created or simultaneously exploited within the partnership. PPP differs from regular public procurement mainly in terms of the occurrence of cooperation, although it is equally important that the realization of tasks is covered by the partnership (Cieślak and Korbus, 2014). Cooperation, in turn, means the need to intensify the relations between its parties and it already sets a path for the formation of these relations, which are both formal and informal (Kusio, 2019).

The formula of PPP allows the public entities to create the most advantageous combination of public and private resources in the implementation of projects. Moreover, such implementation of initiatives allows for increased investment efficiency of invested resources (Takmazyan et al., 2019). From the Polish perspective, it is also due to the statutory provisions of the initiator of PPP - the public party. This party takes the decision to conclude a partnership agreement which is possible due to the statutory provisions (Blicharz, 2010). However, as the local problems are best known by social stakeholders such as local NGOs there is a strong recommendation for the consultation of the priority of actions with these stakeholders.

To obtain information about the situation of PPP in Poland, where, according to the literature, the level of development of PPPs is still insufficient, acquiring information about the implemented projects has been made. The analysis of five case studies has been done and from the descriptions of implemented initiatives in the formula of PPPs the social and human factors have been identified. It has been found that in the context of Poland as the 
economy is not yet fully developed in terms of PPPs, there is a low level of significance of those social elements. Still, the key role is played by the institutionalization, regulations and financial benefits. For the recommendation purposes, the engagement of third sector actors should be stronger to accelerate PPPs development even to the emergence of the transversal partnerships (TPs). This would require stronger social orientation and cooperation with the social stakeholders.

The results of the research conducted in the dimension of literary analysis and in the comparative analysis of the case studies indicate the growing importance of social partners at the moment of entering into PPP initiatives, as well as at the moment of their implementation. On one hand, therefore, the conceptual phase of creating partnerships is mentioned, while on the other hand, in the implementation phase, social participation concerns the consultation of results and their confrontation with the expected effects. The above-mentioned results imply the need for research in the scope of realizing PPPs and in particular the scope of possibilities of increasing the usefulness of the implemented solutions. The issues of social utility level research and in particular their financial quantification, concern the stage of evaluation of the proposed initiatives. The economic evaluation includes the analysis of social utility, but the importance of the social factor indicates that the level of the social utility of PPP projects is a very important factor. An indepth analysis of its importance could allow for a better adjustment of planned initiatives to the real social needs. It is also a natural reference to practical implications. Among them, the improvements in the selection of the best projects to be implemented in the field of PPPs can be indicated.

The practical implications of the results of this work include recommendations on the procedures for implementing PPPs. It seems that the participation of social partners would allow for a better adjustment of planned initiatives to the real social needs in a given region. Taking into account the research on the level of development of the regions following the application of public-private initiatives, the level of social involvement, either in the conceptual or implementation phase of PPP projects, may give a more accurate picture of the stage of this development. The higher the level of social participation, the greater this development is, as shown by the practice of countries with a rich PPP tradition.

\section{Summary}

The initiators of the PPPs are in Poland mainly public entities and these partnerships are mainly related to public administration and business. In countries where these partnerships started to bring positive results, the group of stakeholders began to expand, while at the same time the formula of engaging business to cooperate in projects for public purposes started to be applied in other countries such as Poland. The development of partnerships is connected with the development of groups of parties whose influence on undertaking and implementation of initiatives is growing. In this respect, globalization and technological development are taking place at the same time as the range of stakeholders in PPP projects is expanding. Increased communication opportunities, thus, positively correlate with the increased interest of stakeholders in the projects. A review of the literature, in particular relating to economies with developed PPPs, clearly shows the trend of broadening the scope of PPP stakeholders, both individuals and institutionalized groups such as associations, foundations, social enterprises, i.e. social economy entities. This underlines social actors' such as third sector entities significant roles, they seem to have the highest level of knowledge about local problems. At the same time, these organizations are not in possession of the 
IJOA

29,6

professional instruments for problem identification. As a substitute to formalized identification mechanisms close relations to local inhabitants are used. The significance of social factors, as well as the human factor in PPP partnership projects, correlates with the increase in access to information and the maturity of democracy and economies. In the context of the constantly developing Polish economy, similar attributes of developing PPPs mean the possibility of obtaining invaluable information to create conditions for accelerating these processes in the legal sphere, among others. PPPs initially discussed in the context of the possibilities of minimizing and distributing risks, as well as providing resources that were in short supply on the part of public institutions, we were increasingly focused on creating social value. Not only is it the primary goal of creating infrastructure projects in which private entities are financially highly involved but it is also a complex project to provide end-users with products and services that best meet social demand. Thus, as indicated in the literature, the participation of public representatives in the implementation of projects is mentioned. The significance of stakeholders is in Poland growing slowly and the importance of social benefits in relation to financial benefits. Therefore, the PPPs should evolve toward third sector actors' engagement who has the best knowledge of local problems and this could raise the social benefit of future PPP initiatives.

\section{References}

Andersen, O.J. (2004), "Public-private partnerships: organisational hybrids as channels for local mobilisation and participation", Scandinavian Political Studies, Vol. 27 No. 1, pp. 1-21.

Anopchenko, T., Gorbaneva, O., Lazareva, E., Murzin, A. and Ougolnitsky, G. (2019), "Modeling publicprivate partnerships in innovative economy: a regional aspect", Sustainability (Switzerland), Vol. 11 No. 20, doi: $10.3390 /$ su11205588.

Argiolas, G., Cabras, S., Dessi, C. and Floris, M. (2000), "Building innovative models of territorial governance”, Journal of Place Management and Development, Vol. 2 No. 3, pp. 178-210.

Blicharz, P. (2010), "rozwój modeli współpracy w formie partnerstwa publiczno prywatnego", Zarządzanie Publiczne: Uwarunkowania, Kierunki, Techniki, Częstochowa: Wydawnictwo Wydziatu Zarządzania Politechniki Czestochowskiej, pp. 9-22.

Bovaird, T. (2004), "Public-private partnerships: from contested concepts to prevalent practice", International Review of Administrative Sciences, Vol. 70 No. 2, pp. 199-216.

Brandenburg, H. (2011), Zarządzanie Lokahnymi Projektami Rozwojowymi, Wydawnictwo Uniwersytetu Ekonomicznego w Katowicach, Katowice.

Carbonara, N. and Pellegrino, R. (2018), "Public-private partnerships for energy efficiency projects: a win-win-win model to choose the energy performance contracting structure", Journal of Cleaner Production, Vol. 170, pp. 1064-1075.

Cieślak, R. and Korbus, B. (Eds) (2014), Partnerstwo Publiczno-Prywatne: od Pomystu Do Wyboru Partnera Prywatnego, Ministerstwo Gospodarki, Warszawa.

Conto, F., Fiore, M. and La Sala, P. (2012), "The metadistrict as the territorial strategy: from set theory and a matrix organization model hypothesis", International Journal on Food System Dynamics, Vol. 3 No. 1, pp. 82-94.

Crouch, C., LeGales, P., Trigiglia, C. and Voeltzhow, H. (2001), Local Production Systems in Europe: Rise or Demise?, Oxford University Press, Oxford.

Dansoh, A., Frimpong, S., Ampratwum, G., Dennis Oppong, G. and Osei-Kyei, R. (2020), "Exploring the role of traditional authorities in managing the public as stakeholders on PPP projects: a case study", International Journal of Construction Management, Vol. 20 No. 6, doi: 10.1080/ 15623599.2020.1725722. 
Delmon, J. (2014), "Private sector investment in infrastructure: project finance", PPP Projects and Risk, World Bank and Kluwer Law International, Washington, DC, pp. 5-9.

Elias, A.A., Cavana, R.Y. and Jackson, L.S. (2002), "Stakeholder analysis for R\&D project management", R\&D Management, Vol. 32 No. 4.

Festa, G., Shams Riad, S.M., Metallo, G. and Cuomo, M.T. (2019), "Enhancing stakeholder networks in wine tourism - evidence from Italian small municipalities", EuroMed Journal of Business, Vol. 15 No. 3.

Fudaliński, J. (2013), "Koncepcja zarządzania społecznego organizacjami trzeciego sektora (zarys problematyki)", Przegląd Organizacji, No. 1, pp. 42-47.

Godlewska, M. (2018), “,wpływ instytucji formalnych i nieformalnych na rozwój partnerstwa publiczno prywatnego w polsce”, Wspótczesna Gospodarka, Vol. 9 No. 2 (29), pp. 57-74.

Hall, D. (2008), "Public-private partnerships (PPPs), summary paper", pp. 1-26, available at: www.psivu. org/publicationsindex.asp (accessed 20 May 2020).

Hellowell, M. and Pollock, A.M. (2010), "Do PPPs in social infrastructure enhance the public interest? Evidence from England's National health service", Australian Journal of Public Administration, Vol. 69, pp. 23-34.

Iacomino, C. (2019), “Commercial contributions and public-private partnerships”, doi: 10.1007/978-3030-15751-7_4.

Jakiel, M. (2019), “Patologie partnerstw międzysektorowych”, Przedsiębiorczość i Zarządzanie, Tom XX, Zeszyt 4, Cz. I, (Ed.) Lichtarski J., pp. 293-306.

Jayasuriya, S., Zhang, G. and Yang, R.J. (2020), "Exploring the impact of stakeholder management strategies on managing issues in PPP projects", International Journal of Construction Management, Vol. 20 No. 6, pp. 666-678, doi: 10.1080/15623599.2020.1753143.

Ke, Y., Wang, S.Q., Chan, A.P.C. and Cheung, E. (2009), "Research trend of public - private partnership in construction journals", Journal of Construction Engineering and Management, Vol. 135 No. 10, pp. 1076-1086.

Kołodziej-Hajdo, M. (2018), "Rola i znaczenie interesariuszy w projektach realizowanych w partnerstwie publiczno-prywatnym", Studia Ekonomiczne, Katowice: Uniwersytet Ekonomiczny w Katowicach, No. 369 , pp. $68-80$.

Korbus, B., Zalewski, D. and Kerner, T. (2016), Katalog Dobrych Praktyk Partnerstwa PublicznoPrywatnego w Obszarze Turystyki, Ministerstwo Sportu i Turystyki, Warszawa.

Kotas, A. (2009), "przesłanki podejmowania współpracy publiczno-prywatnej w kontekście uwarunkowań realizacji projektów w formule PPP”, Studia Ekonomiczne, Zeszyty Naukowe Uniwersytetu Ekonomicznego w Katowicach, No. 382, pp. 80-90.

Kozarkiewicz, A. and Bochenek, M. (2018), "Determinanty współpracy międzyorganizacyjnej w sektorze publicznym w Polsce - prezentacja wyników badań empirycznych", Studia Ekonomiczne, Zeszyty Naukowe Uniwersytetu Ekonomicznego w Katowicach, No. 369, pp. 81-92.

Kusio, T. (2019), Więzi Relacyjne Uczelni z Biznesem, Wydawnictwa AGH, Kraków.

Kwak, Y.H., Chih, Y.Y. and Ibbs, C.W. (2009), "Towards a comprehensive understanding of publicprivate partnerships for infrastructure development”, California Management Review, Vol. 51 No. 2, pp. 51-78.

Lank, E. (2007), Collaborative Advantage, Palgrave Macmillan, New York, NY.

Laplane, A. and Mazzucato, M. (2020), "Socializing the risks and rewards of public investments: economic, policy, and legal issues", Research Policy: X, Vol. 2, doi: 10.1016/j.repolx.2020.100008.

Lojko, M. (2018), "Partnerstwo lokalne w ekonomii społecznej jako nowy paradygmat budowania spójności społecznej”, Kwartalnik Kolegium Ekonomiczno-Spolecznego. Studia i Prace, No. 2, pp. 39-57.
Analysis of an evolving phenomenon 
IJOA 29,6

McKenzie, S. (2004), Social Sustainability: Towards Some Definitions, Hawke Research Institute, University of South Australia Magill.

Makieła, Z. (2008), Przedsiębiorczość Regionalna, Difin, Warszawa.

Maraña, P., Labaka, L. and Sarriegi, J.M. (2020), "We need them all: development of a public private people partnership to support a city resilience building process", Technological Forecasting and Social Change, Vol. 154, doi: 10.1016/j.techfore.2020.119954.

Mouraviev, N. and Kakabadse, N.K. (2016), "Conceptualizing public-private partnerships: a critical approach of approaches to meanings and forms", Society and Business Review, Vol. 11 No. 2, pp. 155-173.

Nordtveit, B. (2005), Use of Public-Private Partnership to Deliver Social Services: Advantages and Drawbacks, Scholarworks, UMarsAmherst.

Parysek, J.J. (1992), Podstawy Gospodarki Lokalnej, Uniwersytet A. Mickiewicza, Poznań.

Pietrzyk, I. (2001), Polityka Regionalna Unii Europejskiej, PWN, Warszawa.

Sedjari, A. (2004), "Public-private partnerships as a tool for modernising public administration", International Review of Administrative Sciences, Vol. 70 No. 2, pp. 291-306.

Song, X., Li, W. and Tian, M.J. (2019), "Research overview on public-private partnership (PPP) project supervision in the field of hydraulic engineering", IOP Conference Series: Earth and Environmental Science, Vol. 330 No. 2, doi: 10.1088/1755-1315/330/2/022019.

Szumowski, W. (2019), “Transparentność jednostek samorządu terytorialnego”, Przegląd Organizacji, No. 5, pp. 47-57.

Takmazyan, A.S., Rukina, S.N., Samoylova, K.N. and Gerasimova, K.A. (2019), "Public private partnership as a tool for the development of educational infrastructure", International Journal of Economics and Business Administration, Vol. VII, pp. 535-544.

Tereszko, W. and Pec, M. (2018), "Współpraca organizacji z sektorów publicznego i biznesowego przy tworzeniu wartości dla interesariuszy na przykładzie projektów partnerstwa publiczno prywatnego w polsce", Studia Ekonomiczne, Zeszyty Naukowe Uniwersytetu Ekonomicznego w Katowicach, No. 361, pp. 252-260.

Ustawa z dnia 19 grudnia. 2008 r. o partnerstwie publiczno-prywatnym (2009), "Dziennik Ustaw", nr 19, poz. 100.

Wang, Y. and Gao, R. (2020), "Risk distribution and benefit analysis of PPP projects based on public participation”, International Journal of Strategic Property Management, Vol. 24 No. 4, pp. 215-225, doi: 10.3846/ijspm.2020.12329.

Węgrzyn, J. (2018), "Does experience exert impact on a public-private partnership performance? The case of Poland", Equilibrium, Vol. 13 No. 3, pp. 509-522, doi: 10.24136/eq.2018.025.

Xue, Y., Temeljotov-Salaj, A., Engebø, A. and Lohne, J. (2020), "Multi-sector partnerships in the urban development context: a scoping review", Journal of Cleaner Production, p. 268, doi: 10.1016/j. jclepro.2020.122291.

Yatsechko, S.S. (2020), "Building an institutional model of interaction between government and business in public-private partnership", in Popkova, E. (Ed.), Growth Poles of the Global Economy: Emergence, Changes and Future Perspectives, Lecture Notes in Networks and Systems, Vol. 73, Springer, Cham, doi: 10.1007/978-3-030-15160-7_71.

Zhang, X. and Chen, S. (2013), "A systematic framework for infrastructure development through public private partnerships”, IA TSS Research, Vol. 36 No. 2, pp. 88-97.

\section{Further reading}

Kruhlov, V.V. and Tereschenko, D.A. (2019), "Public-private partnership as tool for developing regional labor potential”, Science and Innovation, Vol. 15 No. 6, pp. 5-13. 


\section{References of case studies:}

1. https://projektarado.pl/

2. www.rodzinna-turystyka.pl/ciekawe-miejsca/podziemia/budowle/arado-podziemna-fabryka-kamiennagora.html

3. www.ppp.gov.p1/zarzadzanie-podziemna-trasa-turystyczna-w-kamiennej-gorze-/

4. http://kolej-debowiec.pl/o-projekcie/

5. www.ppp.gov.pl/swiadczenie-uslug-utrzymania-i-zarzadzania-infrastruktura-sportowo-rekreacyjnana-stoku-debowca-w-bielsku-bialej-/

6. www.zpp.pl/artykul/1673-kompleks-mineralnych-basenow-w-solcu-zdroju-dobra-praktyka-ppp

7. www.ppp.gov.pl/koncesja-na-roboty-budowlane-dla-projektu-kompleks-mineralnychbasenow-w-solcu-zdroju-l

8. www.ppp.gov.p1/wylonienie-operatora-centrum-kongresowo-kulturalnego-zamek-ksiaz-l

9. www.pb.pl/biznes-w-zamku-ksiaz-713452

10. http://bip.um.walbrzych.pl/artykul/706/12654/ogloszenie-o-koncesji-wylonienie-operatora-centrumkongresowo-kulturalnego-zamek-ksiaz-ckkzk

11. www.bip.um-dusznikizdroj.dolnyslask.pl/dokument,iddok,1745,idmp,93,r,r

\section{Corresponding author}

Tomasz Kusio can be contacted at: kusiot@uek.krakow.pl

For instructions on how to order reprints of this article, please visit our website: 